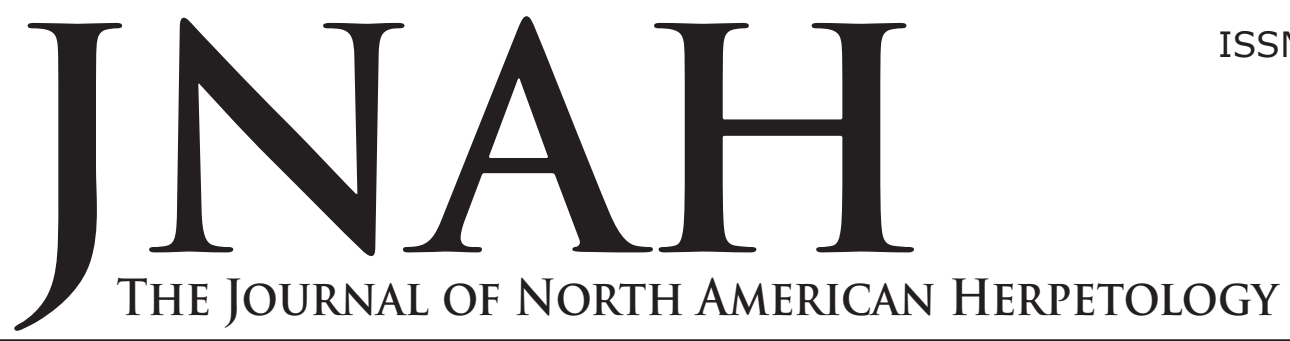

ISSN 2333-0694

Volume 2021, Number 1

June 2021

journals.ku.edu/jnah

\title{
THE CHYTRID BLINDERS 2.0: HOW ARE WE DOING?
}

\author{
AMANDA L.J. DUFFUS* \\ Department of Natural Sciences, \\ School of Nursing, Health, and Natural Sciences, \\ Gordon State College, Barnesville, GA, USA \\ *Corresponding Author: Email: aduffus@gordonstate.edu
}

\begin{abstract}
Amphibians are declining around the world and infectious diseases are thought to play a key role in these declines, along with habitat destruction and other environmental factors. Since the late 1900s, several emerging infections have been identified in amphibians. The chytrids, of which there are two known to affect amphibians, Batrachochytrium dendrobatidis, and B. salamandrivorans, and ranaviruses are perhaps the most well-known and studied. There are also other, lesser known and less studied, pathogenic agents such as Perkinsea spp. and herpesviruses; that have emerged in approximately the same timeline, which may also be contributing to amphibian population dynamics. In this piece we examine the progress that has been made over the past decade in understanding 'The Big Three' and specifically how the emergence of B. salamandrivorans has brought together much of the amphibian disease world in the last half of the 2010s.
\end{abstract}

Key Words: Amphibian declines, Infection, Disease, Emerging infection, Batrachochytrium dendrobatidis, B. salamandrivorans, Ranavirus

Amphibians as a group are one of the most threatened vertebrate groups on Earth (Stuart et al. 2004; Ceballos et al. 2017). There are many factors that have been involved in the decline, and in some cases extinction of these animals, and infectious diseases have played a large part in many of these events. For example, the emergence of Batrachochytrium dendrobatidis (Bd), has resulted in the decline of over 500 species of amphibian and is considered to be the causative agent of the extinction of at least 90 others (Scheele et al. 2019). There are two other major infectious agents that have emerged as potential drivers of amphibian population dynamics, the ranaviruses and another chytrid fungus, $B$. salamandrivorans (Bsal). There are other pathogenic agents that have also emerged over the past couple of decades in amphibians and they include Perkinsea spp. (Isodoro-Ayza et al. 2017; Karwacki et al. 2018) and herpesviruses (Origgi et al. 2017 \& 2018; Franklinos et al. 2018). However, much less is known about their epidemiology and larger scale impacts on amphibian populations where they have emerged.

In 2010, Duffus lamented that many amphibian morbidity and mortality events were 'under-investigated', meaning that the causes were not fully explored and many failed to link the presence of an infection with a potential pathogen and the pathology of the event. Over the past decade, many new advances have been made in diagnostic techniques, as well as in linking the infection presence with the pathology of morbidity and mortality events in North America and Europe. I believe this is the direct result of the emergence of Bsal in European salamander species and the threats that it could pose if, in fact, it is introduced to other areas of the globe.

\section{Ranaviruses}

First described in Northern Leopard Frogs (Rana pipiens) purchased for laboratory use in North America (Granoff et al. 1965), it was not until the mid-1980s and early-1990s that they were associated with morbidity and mortality events in wild amphibians (Australia: Spear and Smith 1992; UK: Cunningham et al. 1996; Canada: Bollinger et al. 1999; USA: Jancovich et al. 1997). Ranaviruses, members of the Iridoviridae, are large double stranded DNA viruses that replicate in the cytoplasm of host cells (Chinchar et al. 2017; Jancovich et al. 2015) and have a wide range of vertebrate hosts (amphibians, reptiles, and fish; Duffus et al. 2015). To date, they have been found on every continent where amphibians are present and are known to affect over 145 species (A.L.J. Duffus, Unpublished Data).

When it comes to amphibians and ranaviruses, they have caused countless morbidity and mortality events. However, in the UK, they have been shown to drive the population dynamics of Common Frogs (Rana temporaria) where they have emerged into decline (Teacher et al. 2010). In Spain, the situation is worse. The emergence of a novel ranavirus, the Common Midwife Toad Virus (CMTV), has resulted in not only the local decline of some amphibian communities, but the local extirpation of some species (Price et al. 2014). In North America, as well as around the rest of the globe, the influences that ranaviruses have on population dynamics can only be speculated on as the long term effects of their emer- 
gence of these viruses has not been well documented. However, this lack of documentation does not mean that there have not been negative effects or that these viruses should not be of conservation concern. Ranaviruses are known to infect Chinese Giant Salamanders (Andrias davidianus; Geng et al. 2011), Red-Legged Frogs (Rana aurora; Mao et al. 1999) and Hellbenders (Cryptobranchus alleganiensis; Souza et al. 2012), all species that are threatened in their native ranges.

Initially, many studies that investigated ranavirus-associated morbidity and mortality events used full pathological and virological methods, such as full necropsy and histopathology, followed up with viral isolation and electron microscopy (e.g. Cunningham et al. 1996). However, with the development of molecular screening techniques and an increase in their accessibility in the early 2000s, many studies began to rely solely on PCR (then quantitative PCR when that became readily available) results and did not necessarily associate the finding of the DNA of ranaviruses to the actual pathology of the morbidity and mortality event. This shift was most likely based on cost effectiveness; it is far less expensive to run a few PCRs than to do a full investigation. However, in the past few years, a return to a more complete investigation of mortality and morbidity events has occurred. The reliance solely on PCR has been augmented with sequence analysis to determine what species/strain of Ranavirus is present, and in many cases a necropsy is performed by trained personnel on at least a subset of affected animals.

The improvements in molecular diagnostic methods of infections are now less often confused with the diagnosis of the presence of a disease, even in cases where only molecular methods have been used. However, it is always best practice to have a multidisciplinary team, which includes a veterinary pathologist to help investigate morbidity and mortality events, especially when they occur in a new area and/or species. This is true regardless of what pathogen is suspected to have been responsible for the event.

\section{Batrachochytrium dendrobatidis (Bd)}

First identified and described by Berger et al. in 1998 and associated with amphibian declines in Australia and Central America, the chytrid fungus, Batrachochytrium dendrobatidis or $\mathrm{Bd}$, is the causative agent of the devastating disease chytridiomycosis. While Bd originated in Asia (O'Hanlon et al. 2018), it has a global distribution and has been implicated in the decline of over 500 species and the extinction of at least 90 species of amphibians (Scheele et al. 2019). This is certainly deserving of the title as the most devastating disease that has ever been documented in wildlife.

While infection with $\mathrm{Bd}$, just as with a ranavirus, does not always result in the development of disease, when disease does develop it can range from mild to severe and eventual death in some cases. Clinical signs of chytridiomycosis include, but are not limited to: anorexia, lethargy, unusual skin sloughing, reddening of the skin (especially in the pelvic area), convulsions, and loss of righting reflex (Nichols et al. 2001). However, these signs of disease in amphibians are encountered with other pathologies (e.g. ranavirosis) and should not be used alone to make a diagnosis. The most common method for diagnosing infection with $\mathrm{Bd}$ is the use of skin swabs followed by qPCR screening. Unfortunately, there is a growing body of evidence that suggests swabbing is not as effective for detecting Bd infections under some circumstances as was once assumed (see Longo et al. 2013, Shin et al. 2014, Clare et al. 2016, and Rebollar et al. 2017 for details). Therefore, it is even more imperative that we exercise caution when encountering an amphib- ian morbidity and/or mortality event to fully investigate the situation using pathological techniques.

Once, a reliance on skin swabs and qPCR for diagnosing infection (and sometimes disease, when appropriate) was the norm: however, the emergence of Batrachochytrium salamandrivorans (Bsal) changed this. Researchers were increasingly aware that other pathogens could be present in their study subjects. Within the Bd research community, in the past few years, a number of huge collaborative works have been published. These works include the discovery of the Asian origin of $\mathrm{Bd}$ (O'Hanlon et al. 2018), the breadth and extreme numbers of amphibians affected by its emergence (Scheele et al. 2019), and the cryptic diversity that is present in Bd globally (Byrne et al. 2019). These collaborations are major and the discoveries that they have made will continue to shape the future of Bd research.

\section{Batrachochytrium salamandrivorans (Bsal)}

This salamander-eating chytrid fungus emerged in 2010 in populations of Fire Salamanders (Salamandra salamandra) in the Netherlands (Martel et al. 2013). The impacts on these populations were devastating, with an initial 96\% decline (Martel et al. 2013). Unfortunately, Bsal spread rapidly to Belgium, France, and Germany (Spitzen-van der Suijs et al. 2016). The clinical signs of Bsal induced chytridiomycosis include lethargy, emaciation, and ulcerations (Martel et al. 2013) very similar to those exhibited by individuals affected by $\mathrm{Bd}$ induced chytridiomycosis. However, during the later stages of infection, when the animal is near death, some of the ulcerations may have a 'volcano'-like appearance where the skin erosion is surrounded by black margins (Martel et al. 2013). Additionally, rapid molecular diagnostic methods have been developed that are capable of detecting the DNA of both Bsal and Bd (see Blooi et al. 2013), and even one method that will screen for the DNA of Bsal, Bd, and ranaviruses (see Standish et al. 2018). However, Thomas et al. (2018) provide a guide to diagnosing Bsal infections and disease while stressing the need for full investigations.

The discovery of Bsal has led to a rapid proliferation in scientific research and the formation of large-scale collaborative projects across Europe and North America. In 2019, Thomas et al. published a strategy for the mitigation of the effects of Bsal across Europe. This work details how Bsal should be dealt with on multiple scales (Thomas et al. 2019) and collaborations will play a key role. In the early 2010s in North America, where Bsal has not yet been found, the Bsal National Task Force for the US was formed (Gray et al. 2015). This large-scale, multidisciplinary, multiorganization task force is poised for Bsal early detection and action (Gray et al. 2015). In addition to this, the Partners in Amphibian and Reptile Conservation (PARC) have created a Disease Task Team, whose work will primarily deal with the imminent threat of Bsal (Gray et al. 2015). These organizations will play key roles in protecting North American salamanders, as the southeastern USA is a global hot spot of salamander diversity.

\section{Concluding Thoughts: How are we doing?}

Over the past decade there have been many developments in amphibian disease research, many of them the product of collaborative projects between scientists and veterinary pathologists. Resources have been developed to track amphibian diseases such as the Global Ranavirus Reporting System (site is currently being revised and rehomed, Brunner et al. In Press) and the Amphibian Disease Portal (https://amphibiandisease. org/) which houses records for both Bd and Bsal. Others have provided guidelines for investigations into morbidity 
and mortality events (e.g. Gray et al. 2017) and information for the collection of samples from morbidity and mortality events (e.g. Duffus et al. 2017). All of these and more have been the result of collaborations, which need to continue if we are going to attempt to monitor and mitigate the effects of emerging infections in amphibians. There are more emerging infections out there that are and will be affecting amphibians than just the 'Big Three', and we must all continue to work together to understand them, and hopefully ward off the possibility of their most horrific outcome, extinction.

\section{ACKNOWLEDGEMENTS}

Special thanks go to Daniel Fogell, Kirsten Hecht, Steve Allain and John George for providing valuable comments that greatly improved the document in both quality and content.

\section{REFERENCES}

Berger, L., R. Speare, P. Daszak, D.E. Green, A.A. Cunningham, C.L. Goggin, R. Slocombe, R.A. Ragan, A.D. Hyatt, K.R. McDonald, H.B. Hines, K.R. Lips, G. Marantelli, and H. Parks. 1998. Chytridiomycosis causes amphibian mortality associated with population declines in the rain forests of Australia and Central America. Proceedings of the National Academy of Sciences of the United States of America. 95:9031-9036.

Blooi, M., F. Pasmans, J.E. Longcore, A. Spitzen-Van Der Sluijs, F. Vercammen, and A. Martel. 2013. Duplex real-time PCR for rapid simultaneous detection of Batrachochytrium dendrobatidis and Batrachochytrium salamandrivorans in amphibian samples. Journal of Clinical Microbiology. 51:4173-4177.

Bollinger, T.K., J. Mao, D. Schock, R.M. Brigham, and V.G. Chinchar. 1999. Pathology, isolation, and preliminary molecular characterization of a novel iridovirus from tiger salamanders in Saskatchewan. Journal of Wildlife Diseases. 35:413-429.

Brunner, J., D. Olson, M.J. Gray, D.L. Miller and A.L.J. Duffus. In Press. Global patterns of ranavirus detections in the Global Ranavirus Reporting System. FACETS.

Byrne, A.Q., V.T. Vredenburg, A. Martel, F. Pasmans, R.C. Bell, D.C. Blackburn, M.C. Bletz, J. Bosch, C.J. Briggs, R.M. Brown, A. Catenazzi, M.F. Lopez, R. Figueroa-Valenzuela, S.I. Ghose, J.R. Jaeger, A.J. Jani, M. Jirku, R.A. Knapp, A. Munoz, D.M. Portik, C. L. Richards-Zawacki, H. Rockney, S.M. Rovito, T. Stark, H. Sulaeman, N.T. Tao, J. Voyles, A.W. Waddle, Z. Yuan, and E.B. Rosenblum.2019. Cryptic diversity of a widespread global pathogen reveals expanded threats to amphibian conservation. Proceedings of the National Academy of Sciences. 18:201908289.

Ceballos, G., P.R. Ehrlick, and R. Dirzo. 2017. Biological annihilation via the ongoing sixth mass extinction signaled by vertebrate population losses and declines. Proceedings of the National Academy of Sciences of the United States of America. E6098-E6096.

Chinchar. V.G., P. Hick, I.A. Ince, J.K. Jancovich, R.E. Marschang, Q. Qin, K. Subramaniam, T.B. Waltzek, R. Whittington, T. Williams and Q-Y. Zhang. 2017. ICTV virus taxonomy profile: Iridoviridae. Journal of General Virology. 98:890-891.

Clare, F., O. Daneil, T.W.J. Garner, and M. Fischer. 2016. Assessing the ability of swab data to determine the true burden of infection for the amphibian pathogen Batrachochytrium dendrobatidis. EcoHealth. 13:360367.

Cunningham, A.A., T.S. Langton, P.M. Bennett, J.F. Lewin, S.E.N. Drury, R.E. Gough and S.K. Macgregor. 1996. Pathological and microbiological findings from inci- dents of unusual mortality of the common frog (Rana temporaria). Philosophical Transactions of the Royal Society of London B. 351:1539-1557.

Daszak, P., L. Berger, and A.D. Hyatt. 2003. Infectious diseases and population declines. Diversity and Distributions. 4:141-150.

Duffus, A.L.J. 2010. Chytrid Blinders: What other disease risks to amphibians are we missing? EcoHealth 6:335-339.

Duffus, A.L.J., H.M.A Fenton, M.J. Gray, and D.L. Miller. 2017. Investigating amphibian and reptile mortalities: A practical guide for wildlife professionals. Herpetological Review. 48:550-557.

Duffus, A.L.J., T.B. Waltzek, A.C. Stöhr, M.C. Allender, M. Gotesman, R.J. Whittington, P. Hick, M.K. Hines, and R.E. Marschang. 2015. Distribution and Host Range of Ranaviruses. Pp. 9-57. In M.J. Gray and V.G. Chinchar (Eds.) Ranaviruses: Lethal Pathogens of Ectothermic Vertebrates. Springer Online. https://doi. org/10.1007/978-3-319-13755-1 2.

Franklinos, L.H.V., J. Rodrigues-Ramos Fernandes, H.B. Hydeskov, K.P. Hopkins, D.J. Everest, A.A. Cunningham, and B. Lawson. 2018. Herpesvirus skin disease in free-living common frogs Rana temporaria in Great Britain. Diseases of Aquatic Organisms. 129: 239-244

Karwacki, E.E., M.S. Atkinson, R.J. Ossiboff, and A.E. Savage. 2018. Novel quantitative PCR assay specific for the emerging Perkinsea amphibian pathogen reveals seasonal infection dynamics. Diseases of Aquatic Organisms. 129:95-98.

Geng Y, Wang KY, Zhou ZY, Li CW, Wang J, He M, Q.Z. Yin and W.M. Lai. 2011. First report of a ranavirus associated with morbidity and mortality in farmed Chinese giant salamanders (Andrias davidianus). Journal of Comparative Pathology. 145:95-102.

Granoff, A., P.E. Came, and K.A. Rafferty Jr. 1965. The isolation and properties of viruses from Rana pipiens: their possible relationship to the renal adenocarcinoma of the leopard frog. Annals of the New York Academy of Sciences. 126:237-255.

Gray, M.J., L.P. Lewis, P. Nanjappa, B. Klocke, F. Pasmans, A, Martel, C. Stephens, G. Parra Olea, S.A. Smith, A. Sacerdote-Velat, M.R. Christman, J.M. Williams and D.H. Olson. 2015. Batrachochytrium salamandrivorans: the North American response and a call for action. PLoS Pathogens. 11:1005251.

Gray, M.J., A.L.J. Duffus, K.H. Haman, R.N. Harris, M.C. Allender, T.A. Thompson, M R. Christman, A. Sacerdote-Velat, L.A. Sprague, J.M. Williams and D.L. Miller. 2017. Pathogen surveillance in herpetofaunal populations: Guidance on study design, sample collection, biosecurity, and intervention strategies. Herpetological Review. 48:334-351.

Isidoro-Ayza, M., J.M. Lorch, D.A. Grear, M. Winzeler, D.L. Calhoun and W.J. Barichivich. 2017. Pathogenic lineage of Perkinsea associated with mass mortality of frogs across the United States. Scientific Reports. 7:10288.

Jancovich, J.K., E.W. Davidson, J.F. Morado, B.L. Jacobs and J.P. Collins. 1997. Isolation of a lethal virus from the endangered tiger salamander Ambystoma tigrinum stebbinsi. Diseases of Aquatic Organisms. 31:161-7.

Jancovich, J.K., Q. Qin, Q-Y. Zhang, and V.G. Chinchar. 2015. Ranavirus replication: molecular, cellular, and immunological events.Pp. 105-139. In M.J. Gray and V.G. Chinchar (Eds.) Ranaviruses: Lethal Pathogens of Ectothermic Vertebrates. Springer Online. https://doi. org/10.1007/978-3-319-13755-1 5

Longo, A.V., D. Rodriguez, D. da Silva Leite, L.F. Toledo, C. Medoza Almeralla, P.A. Burrowes, and K.R. Zamudio. 2013. ITS1 copy number varies among Batra- 
chochytrium dendrobatidis strains: Implications for qPCR estimates of infection intensity from field-collected amphibian skin swabs. PLoS ONE. 8:e59499.

Mao, J., D.E. Green, G. Fellers, and V.G. Chinchar. 1999. Molecular characterization of iridoviruses isolated from sympatric amphibians and fish. Virus Research. 63:4552.

Martel, A., A. Spitzen-van der Sluijs, M. Blooi, W. Bert, R Ducatelle, M.C. Fisher, A. Woeljest W. Bosman, K. Cheirs, F. Bossuyt, and F. Passmans. 2013. Batrachochytrium salamandrivorans sp. nov. causes lethal chytridiomycosis in amphibians. Proceedings of the National Academy of Sciences. 2013:201307356.

Nichols, D.K., E.W. Lamirand, A.P. Pessier, and J.E. Longcore. 2001. Experimental transmission of cutaneous chytridiomycosis in dendrobatid frogs. Journal of Wildlife Diseases 37:1-11.

O'Hanlon S.J., A. Rieux, R.A. Farrer, G.M. Rosa, B Waldman, A. Bataille, T.A. Kosch, K.A. Murray, B. Brankovics, M. Fumagalli, M.D. Martin, N. Wales, M. Alvarado-Rybak, K.A Bates, L. Berger, S. Boll, L. Brookes, F. Clare, E.A. Courtois, A.A. Cunninham, T.M. Docherty-Bone, P. Ghosh, D.J. Gower, W.E. Hintz, J. Hoglund, T.S. Jenkinson, C-F. Lin, A. Laurila, A. Loyau, A. Martel, S. Meurling, C. Miaud, P. Minting, F. Pasmans, D.S. Schmeller, B.R. Schmidt, J.M.G, Shelton, L.F. Skerratt, F. Smith, C. Soto-Azat, M. Spagnoletti, G. Tessa, L. F. Toledo, A. Valenzuela-Sanchez, R. Verster, J. Voros, R. J. Webb, C. Wierzbicki, E. Wombell, K.R. Zamudio, D.M. Aanensen, T.Y. James, M.T.P. Gilbert, C. Weldon, J. Bosch, F. Balloux, T.W.J. Garner, and M.C Fisher. 2018. Recent Asian origin of chytrid fungi causing global amphibian declines. Science. 360:621-627.

Origgi, F.C., B.R. Schmidt, P. Lohman, P. Otten, E. Akdesir, V. Gaschen, L. Aguilar-Bultet, T. Wahli, U. Sattler, and H.M. Stoffel. 2017. Ranid herpesvirus 3 and proliferative dermatitis in free-ranging wild common frogs (Rana temporaria). Veterinary Pathology. 54:686-694.

Origgi, F.C., B.R. Schmidt, P. Lohman, P. Otten, R.K. Meier, S.R.R. Pisano, G. Moore-Jones, M. Tecilla, U. Sattler, T. Wahli, V. Gaschen, and M.H. Stoffell. 2018. Bufonid herpesvirus 1 (BfHV1) associated dermatitis and mortality in free ranging common toads (Bufo bufo) in Switzerland. Scientific Reports. 8:14737

Price, S.J., T.W.J. Garner, R.A. Nichols, F. Balloux, C. Ayres, A.M.C. de Alba AMC, and J. Bosch. 2014. Collapse of amphibian communities due to an introduced Ranavirus. Current Biology. 24:2586-2591.

Rebollar, E.A., D. C. Woodhams, B. LaBumbard, J. Kielgast, and R.N. Harris. 2017. Prevalence and pathogen load estimates for the fungus Batrachochytrium dendrobatidis are impacted by ITS DNA copy number variation. Diseases of Aquatic Organisms. 123:213-226.
Scheele, B.C., F. Pasmans, L.F. Skerratt, L. Berger, A Martel A, W. Beukema, A. Acevedo, P.A. Burrowes, T. Carvalho, A. Catenazzi, I. de la Riva, M.C. Fisher, S.V. Flechas, C.N. Foster, P. Frias-Alvarez, T.W.J, Garner, B. Gratewicke, J.M. Guayasamin, M. Herschfeld, J.E. Kolby, T.A. Kosch, E. La Marca, D.B. Lindenmayer, K.R. Lips, A.V. Longo, R. Maneyro, C.A. McDonald, J. Mendelson III, P. Palacios-Rodrigues, G. Parra-Olea, C.L. Richards-Zawacki, M-O. Rodel, S.M. Rovito, C. Soto-Azat, L.F. Toledo, J. Voyles, C. Weldon, S.M. Whitfield, M. Wilkinson, K.R. Zamudio, S. Canessa. 2019 Amphibian fungal panzootic causes catastrophic and ongoing loss of biodiversity. Science. 363:1459-1463.

Shin, J., A. Bataille, T.A Kosch, and B. Waldham. 2014 Swabbing often fails to detect amphibian chytridiomycosis under conditions of low infection load. PLoS ONE. 9:e111091

Souza MJ, Gray MJ, Colclough P, Miller DL (2012) Prevalence of infection by Batrachochytrium dendrobatidis and Ranavirus in eastern hellbenders (Cryptobranchus alleganiensis alleganiensis) in eastern Tennessee. Journal of Wildlife Diseases. 48:560-566.

Speare R. and J.R. Smith. 1992. An iridovirus-like agent isolated from the ornate burrowing frog, Limnodynates in northern Australia. Diseases of Aquatic Organisms. 14:51-57.

Spitzen-van der Sluijs, A., A. Martel, J. Asselberghs, E.K Bales, W. Beukema, M.C. Bletz MC, L. 2016. Expanding distribution of lethal amphibian fungus Batrachochytrium salamandrivorans in Europe. Emerging Infectious Diseases. 22:1286.

Standish, I., E. Leis, N. Schmitz, J. Credico, S. Erickson, J. Bailey, J. Kerby, K. Phillips, and T. Lewis. 2018) Optimizing, validating, and field testing a multiplex qPCR for the detection of amphibian pathogens. Diseases of Aquatic Organisms. 129:1-13.

Stuart, S.N., J.S. Chanson, N.A. Cox, B.E. Young, A.S.L. Rodrigues, D.L. Fischman, and R.W. Waller. 2004. Status and trends of amphibian declines and extinctions worldwide. Science. 306:1783-1786.

Teacher, A.G.F., A.A. Cunningham, T.W.J. Garner. 2010. Assessing the long-term impact of Ranavirus infection in wild common frog populations. Animal Conservation. 13:514-522.

Thomas, V., M. Blooi, P. Van Rooij, S. Van Praet, E. Verbrugghe, E. Grasselli, M. Lukac, S., Smith, F. Pasmans and A. Martel. 2018. Recommendations on diagnostic tools for Batrachochytrium salamandrivorans. Transboundary and Emerging Diseases. 65:e478-e488.

Thomas, V., Y. Wang, P. Van Rooij, E. Verbrugghe, V. Baláž, J. Bosch, A.A. Cunningham, M.C. Fisher, T.W.J. Garner, M.J. Gilbert, and E. Grasselli. 2019. Mitigating Batrachochytrium salamandrivorans in Europe. Amphibia-Reptilia. 40:265-90. 